\title{
Editorial
}

\section{Eberhard F. Mammen Award Announcements: Part II-Young Investigator Awards}

\author{
Emmanuel J. Favaloro, PhD, FFSc (RCPA) ${ }^{1}$ \\ ${ }^{1}$ Department of Haematology, Institute of Clinical Pathology and \\ Medical Research (ICPMR), Sydney Centres for Thrombosis and \\ Haemostasis, Westmead Hospital, Westmead, Australia
}

Semin Thromb Hemost 2018;44:81-88.

Welcome to another of our Eberhard F. Mammen award announcements. As noted previously, ${ }^{1-3}$ Thieme, the publisher of Seminars in Thrombosis \& Hemostasis, has created the "Eberhard F. Mammen Excellence in Thrombosis and Hemostasis Awards" in honor of Eberhard Mammen (-Fig. 1), and in recognition of his contribution to this field and to the journal that he both founded and steered for over three decades. These awards began in 2009, under two categories; the current award details and conditions are as follows:

$>$ Most popular article awards: Awarded to the authors of the most popular articles published in Seminars in Thrombosis $\mathcal{E}$ Hemostasis. The awards are determined by the Editor in Chief on the basis of user statistics from Thieme e-Journals from the preceding 2 years. Prefaces, Errata, Letters to the Editor, and Editorials, and previous award winning articles, are excluded from further consideration of these awards, which currently comprise two categories-one for "Open Access" articles, and another for a "General Category." There are two major cash prizes of US $\$ 1,000$ for each category. In addition, winners of the "General Category" awards are granted "open access" status for these articles thereafter.

$>$ Young Investigator awards: Best presentation or meeting abstract by a young investigator-as presented or delivered to an international or large regional meeting on a topic related to the fields of thrombosis and hemostasis, and whose subject matter is determined to be in the spirit of Dr. Mammen. Up to six cash prizes of US $\$ 1,000$ are awarded in any given year. There are some additional considerations and conditions for the award, and awardees are expected to prepare a review or other paper related to the topic of their presentation

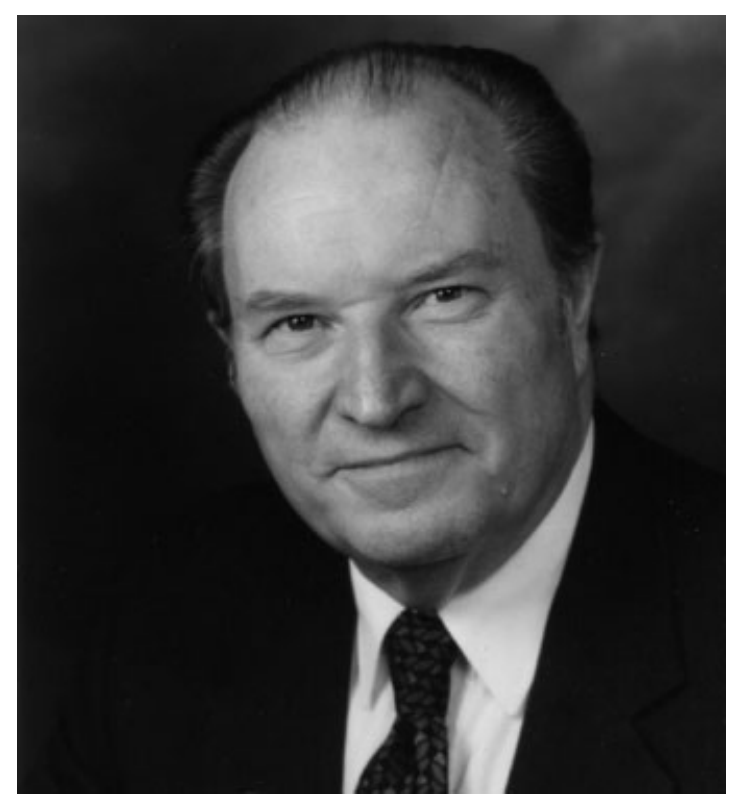

Fig. 1 Eberhard F. Mammen (1930-2008).

(or as otherwise agreed) for publication in Seminars in Thrombosis \& Hemostasis. After nominations are received, the awardees are selected by a vote of the Senior Editors of Seminars in Thrombosis \& Hemostasis. Any potential conflicts of interest are managed by first identifying these, and excluding those with potential conflicts from voting.

Further details of the awards and the award winners are posted online (<https://www.thieme-connect.com/products/ ejournals/journal/10.1055/s-00000077>), and previous award winner announcements are also available in print. ${ }^{4-16}$
Address for correspondence E. J. Favaloro, PhD, FFSc (RCPA), Department of Haematology, Institute of Clinical Pathology and Medical Research (ICPMR), Sydney Centres for Thrombosis and Haemostasis, Westmead Hospital, Westmead, NSW, 2145, Australia (e-mail: emmanuel. favaloro@health.nsw.gov.au).
Issue Theme Extrahemostatic Functions of Platelets and Coagulation Factors; Guest Editors: Roger J. S. Preston, PhD, and Ton Lisman, PhD.
Copyright $\odot 2018$ by Thieme Medical Publishers, Inc., 333 Seventh Avenue, New York, NY 10001, USA. Tel: +1(212) 584-4662.
DOI https://doi.org/ 10.1055/s-0038-1625982. ISSN 0094-6176. 
The winners of the 2017 Eberhard F. Mammen awards for the most popular articles from Seminars in Thrombosis $\mathcal{E}$ Hemostasis for the period of 2015 to 2016 inclusive were announced in an earlier issue. ${ }^{16}$ It is therefore with great pleasure that we would like to announce the winners of the latest round of Young Investigator awards.

As mentioned above, the Young Investigator awards represent winners of the best presentation or meeting abstract by a young investigator-as presented or delivered to an international or large regional meeting on a topic related to the fields of thrombosis and hemostasis, and whose subject matter is determined to be in the spirit of Dr. Mammen. There are additional considerations given that the nominees' presentations are not always seen by all of the possible award nominators, being drawn from the editorial team of the journal. The latest winners are identified below and also listed in -Table 1. The latest awardees were all derived from the latest ISTH 2017 meeting, held in Berlin in July, 2017. Due to personal conflicts of interest in relation to award nominees, I excluded myself from voting on this occasion.

Laura Franco (-Fig. 2) is a clinical research fellow at the Internal Medicine Department of University of Perugia, Italy. She received her degree in Medicine in 2010 at the School of Medicine of the University of Perugia, Italy. She completed a

Table 1 Latest young investigator awardees

\begin{tabular}{|c|c|c|}
\hline Awardee & $\begin{array}{l}\text { Current } \\
\text { placement }\end{array}$ & $\begin{array}{l}\text { Presentations } \\
\text { awarded }\end{array}$ \\
\hline Laura Franco & $\begin{array}{l}\text { Internal Medicine, } \\
\text { University of Peru- } \\
\text { gia, Italy }\end{array}$ & $\begin{array}{l}\text { Mortality in Patients } \\
\text { with Intracerebral } \\
\text { Hemorrhage Asso- } \\
\text { ciated with Vitamin K } \\
\text { Antagonists, Direct } \\
\text { Oral Anticoagulants, } \\
\text { Antiplatelets or No } \\
\text { Antithrombotic } \\
\text { Therapy }\end{array}$ \\
\hline $\begin{array}{l}\text { Elodie } \\
\text { Laridan }\end{array}$ & $\begin{array}{l}\text { Cardiovascular } \\
\text { Sciences, Kulak, } \\
\text { Belgium }\end{array}$ & $\begin{array}{l}\text { Neutrophil Extracel- } \\
\text { lular Traps in Thrombi } \\
\text { from Patients with } \\
\text { Acute Ischemic } \\
\text { Stroke }\end{array}$ \\
\hline $\begin{array}{l}\text { Leonardo } \\
\text { Pasalic }\end{array}$ & $\begin{array}{l}\text { Haematology, Insti- } \\
\text { tute of Clinical } \\
\text { Pathology and } \\
\text { Medical Research, } \\
\text { New South Wales } \\
\text { Health Pathology, } \\
\text { Australia }\end{array}$ & $\begin{array}{l}\text { Patients with Coron- } \\
\text { ary Artery Disease } \\
\text { Have a Pathological } \\
\text { P2Y12 Platelet } \\
\text { Response with } \\
\text { Heightened Procoa- } \\
\text { gulant Platelet } \\
\text { Potential }\end{array}$ \\
\hline $\begin{array}{l}\text { Yvonne } \\
\text { Brennan }\end{array}$ & $\begin{array}{l}\text { Clinical Haematol- } \\
\text { ogy, Westmead } \\
\text { Hospital, Australia }\end{array}$ & $\begin{array}{l}\text { Dental Extractions on } \\
\text { NOACs without Stop- } \\
\text { ping Therapy } \\
\text { (DENTST) Study }\end{array}$ \\
\hline $\begin{array}{l}\text { Georgia } \\
\text { McCaughan }\end{array}$ & $\begin{array}{l}\text { Australian Red } \\
\text { Cross Blood } \\
\text { Service, Sydney, } \\
\text { Australia }\end{array}$ & $\begin{array}{l}\text { Choice of Anticoagu- } \\
\text { lation in the Obese }\end{array}$ \\
\hline
\end{tabular}

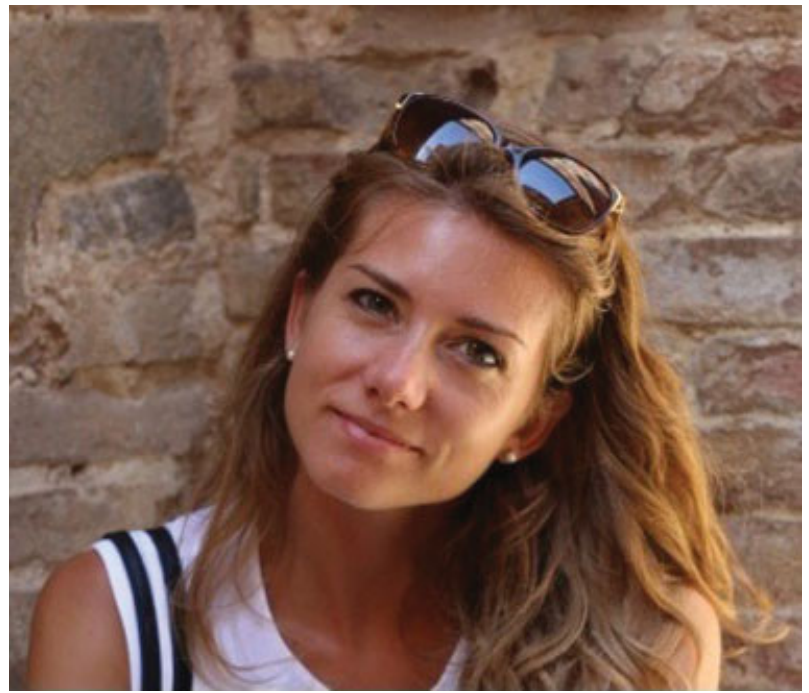

Fig. 2 Young Investigator Award winner Laura Franco.

residency in Emergency Medicine and has worked in the internal medicine ward at the Vascular and Emergency Medicine-Stroke Unit Institute, University of Perugia, Italy. Her main interests are hemorrhagic complications associated with anticoagulant therapy and she is involved in national and international research projects in the field of anticoagulant treatment.

Elodie Laridan (-Fig. $\mathbf{3}$ ) is currently a PhD student at the Laboratory for Thrombosis Research, Kortrijk, Belgium. After her graduation in 2013 from the University of Leuven in Belgium as a biomedical scientist, she first worked as a clinical assistant at the university hospital in Leuven for a

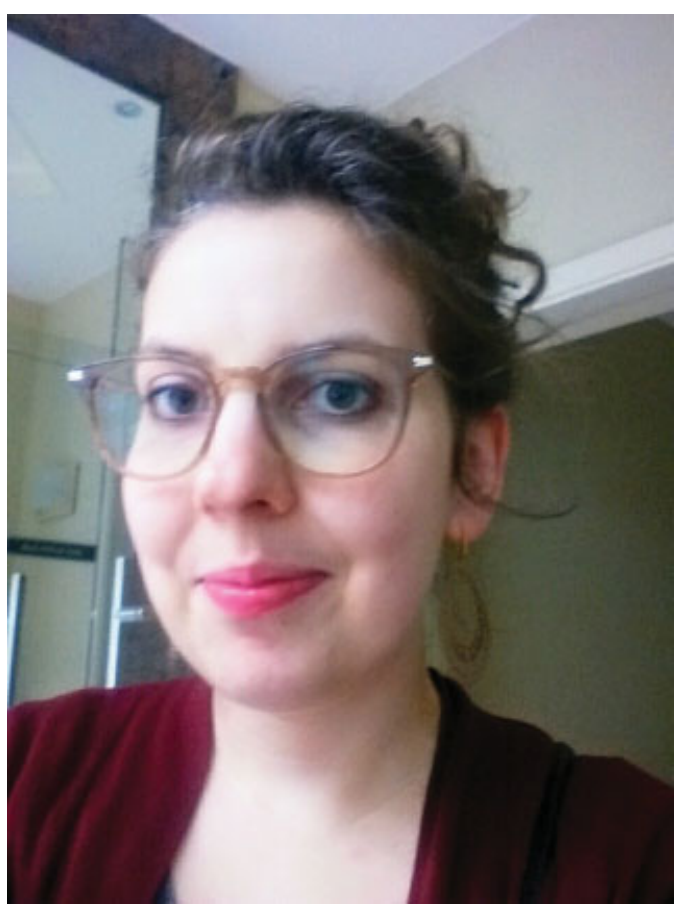

Fig. 3 Young Investigator Award winner Elodie Laridan. 
year. Her combined interests for basic and clinical research made her join the laboratory in Kortrijk in a project focused on neutrophil extracellular traps and their involvement in ischemic stroke.

Leonardo Pasalic (-Fig. 4) is a hematopathologist and clinical hematologist, currently placed at the Institute for Clinical Pathology and Medical Research, NSW Health Pathology, Westmead Hospital, Sydney, Australia. He received his MD in 2004 from the University of New South Wales (UNSW), Australia. He then completed internal medicine and dual laboratory and clinical hematology training at Westmead Hospital. He received his PhD from the Faculty of Medicine, UNSW, Australia, in 2016, for which he investigated various laboratory assays for characterization of procoagulant platelets and their role in immunothrombosis. His current clinical focus is on venous thromboembolism and anticoagulants, as well as bleeding disorders. He has continued to pursue his interests in assay development in the field of hemostasis and thrombosis, with particular interest in use of flow cytometry for evaluation of platelet-based biomarkers in clinical diagnostics and translational research.

Yvonne Brennan (-Fig. 5) obtained her medical degree from The University of Sydney in 2006, before completing residency and basic physicians training at various tertiary hospitals in Sydney. She is currently in her final year of hematology training with the Royal Australasian College of Physicians (RACP) and the Royal College of Pathologists of Australasia (RCPA). Dr. Brennan is also currently a thrombosis and hemostasis fellow at Westmead Hospital, where she has an outstanding opportunity to pursue her areas of interests, including thrombosis, hemostasis, and obstetric hematology.

Georgia McCaughan (-Fig. $\mathbf{6}$ ) is a joint RCPA/RACP Haematology Registrar, currently completing a rotation in Transfusion Medicine at the Australian Red Cross Blood Service in

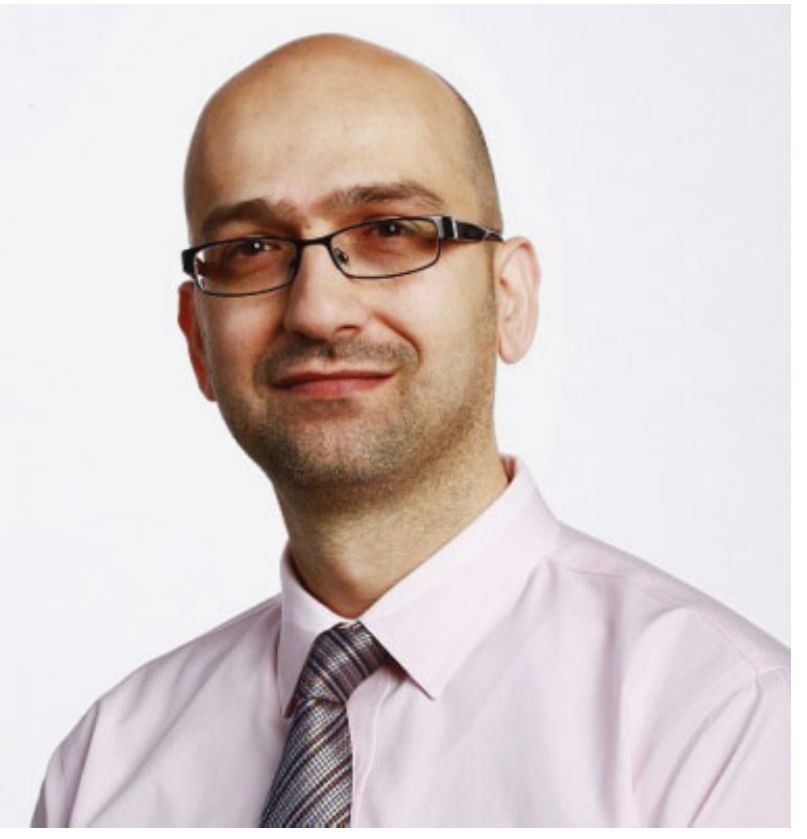

Fig. 4 Young Investigator Award winner Leonardo Pasalic.

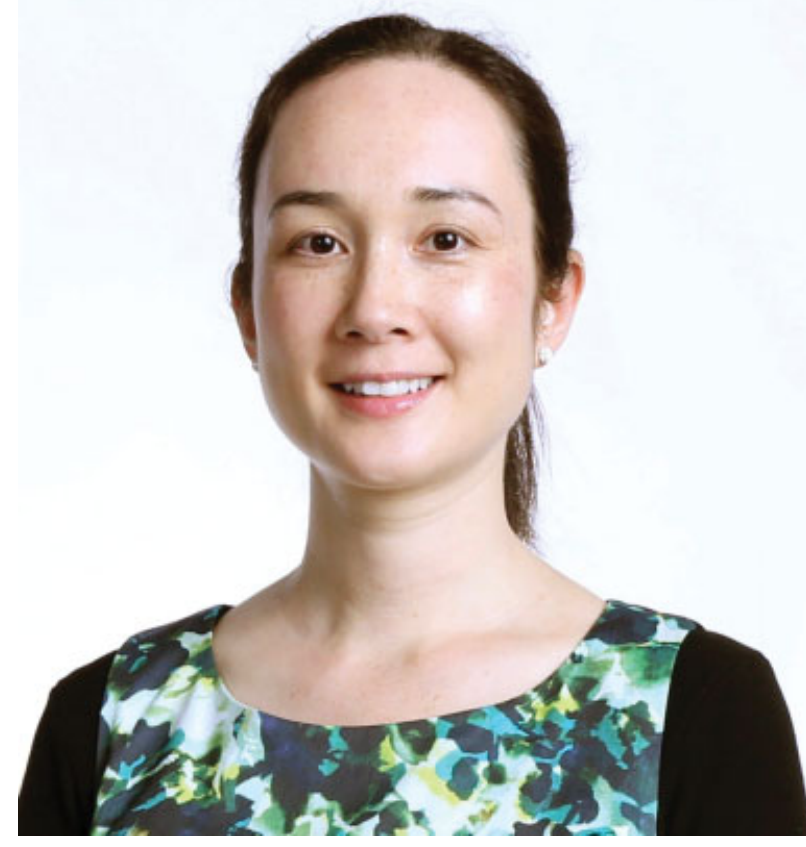

Fig. 5 Young Investigator Award winner Yvonne Brennan.

Sydney. She received her Bachelor of Medicine/Bachelor of Surgery from the University of Sydney in 2011, graduating with the University Medal. Her current research aims to elucidate the most appropriate anticoagulation strategy in the obese, and she is setting up an Australian and New Zealand prospective registry to examine anticoagulant prescribing patterns, drug-specific levels, and clinical outcomes in this patient group. She is also interested in the diagnostic

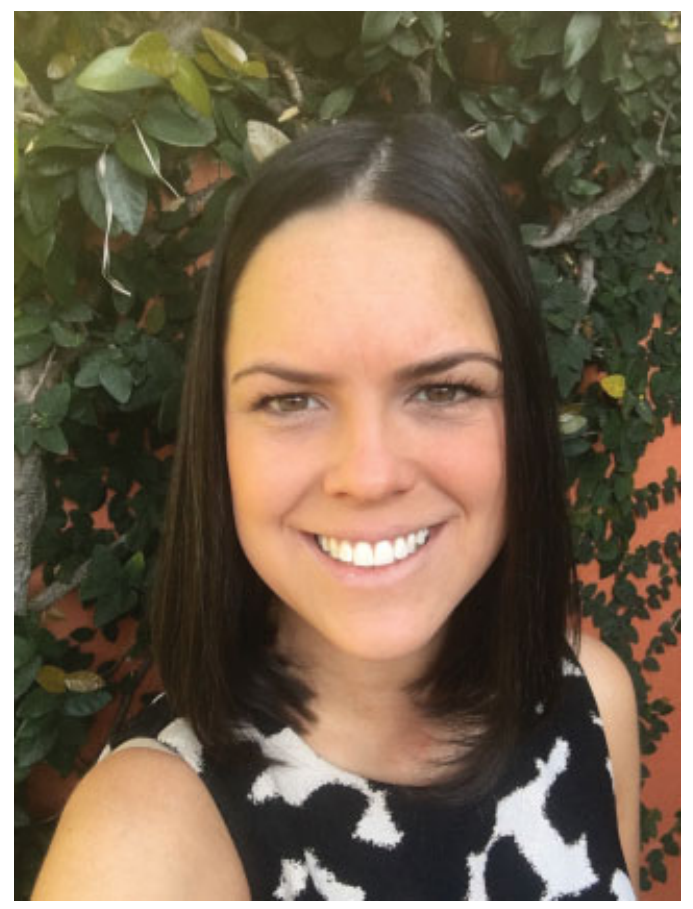

Fig. 6 Young Investigator Award winner Georgia McCaughan. 
approach to heparin-induced thrombocytopenia (HIT), in particular the availability of rapid diagnostic assays to assist in clinical decision making. Georgia is a Clinical Associate Lecturer with Sydney Medical School and is actively engaged in medical student teaching.

All award winners were elated to hear that they had been selected to receive an Eberhard F. Mammen Young Investigator award, and provided the following additional commentary:

"I am honored to be a recipient of the 2017 Eberhard F. Mammen Young Investigator Award. My presentation was on Mortality in Patients with Intracerebral Haemorrhage Associated with Vitamin K Antagonists, Direct Oral Anticoagulants, Antiplatelets or No Antithrombotic Therapy. I sincerely thank the Award Committee as well as my supervisors Drs. Giancarlo Agnelli, Cecilia Becattini, and Maurizio Paciaroni, and all colleagues who have supported me with my research."

$$
\text { - Laura Franco (-Fig. 2) }
$$

"I am very honored to have received an Eberhard F. Mammen Young Investigator Award. I deeply appreciate the recognition for my project. This award acknowledges a team effort and the hard work that has been put into the project. Therefore, I would like to thank Prof. De Meyer and my colleagues from the Laboratory for Thrombosis Research for having given me the opportunity to be part of this new research angle to investigate treatments for ischemic stroke."

- Elodie Laridan (-Fig. 3)

"I am incredibly honored to have been selected to receive an Eberhard F. Mammen Young Investigator Award. This award acknowledges our research investigating the role of procoagulant platelets in atherothrombotic disorders. This award would not have come to realisation without a truly collaborative effort and without the contributions of Drs. Edwina Wing-Lun, Jerrett Lau and Heather Campbell. I would like to take this opportunity to acknowledge my supervisor
Dr. Vivien Chen and all my colleagues at Lowy Cancer Research Institute (Sydney, Australia) for their ongoing support and contribution to this work."

$$
\text { - Leonardo Pasalic (-Fig. 4) }
$$

"I was thrilled and honored to be a recipient of an Eberhard F. Mammen Young Investigator Award, and to thus be recorded alongside the impressive list of prior award winners. I would like to thank my dental collaborators who have made possible the work for which I was nominated. I feel very fortunate and grateful to have Dr. Jennifer Curnow as my mentor, and also wish to thank the Editor in Chief of STH, Dr. Emmanuel Favaloro, another of my mentors, for this opportunity to shine."

-Yvonne Brennan (-Fig. 5)

"I was extremely honored to receive an Eberhard F. Mammen Young Investigator Award. The project for which I was nominated, and our prospective registry in development, would not have happened without the support and direction of my supervisors Dr. Helen Crowther and Dr. Jennifer Curnow. I would also like to thank Dr. Leonardo Pasalic and Dr. Emmanuel Favaloro for their support and enthusiasm in encouraging me to pursue research in thrombosis and haemostasis."

- Georgia McCaughan (-Fig. 6)

In keeping with previous editorials, I have again reviewed the Young Investigator awardees from previous years as well as the outcome of their subsequent submissions ${ }^{17-50}$ to Seminars in Thrombosis \& Hemostasis, and as summarized in - Table 2. I previously mentioned my personal gratification that most of the papers from earlier years have subsequently appeared in several annual top 100 listings. . $^{9} 10,12,14-16$ Of further interest, one of these papers actually won one of the Most Popular awards in 2014 (within the Open Access Category) based on

Table 2 Young investigator awardees from previous years

\begin{tabular}{|l|l|l|}
\hline Awardee & $\begin{array}{l}\text { Year } \\
\text { awarded }\end{array}$ & Publication arising \\
\hline Willem M. Lijfering & 2009 & $\begin{array}{l}\text { Lijfering WM, Flinterman LE, Vandenbroucke JP, Rosendaal FR, Cannegieter SC. } \\
\text { Relationship between venous and arterial thrombosis: a review of the literature from a } \\
\text { causal perspective. Semin Thromb Hemost 2011;37(8):885-896 }\end{array}$ \\
\hline Salley Pels & 2009 & $\begin{array}{l}\text { Pels SG. Current therapies in primary immune thrombocytopenia. Semin Thromb } \\
\text { Hemost 2011;37(6):621-630 }\end{array}$ \\
\hline Adam Cuker & 2010 & $\begin{array}{l}\text { Cuker A. Current and emerging therapeutics for heparin-induced thrombocytopenia. } \\
\text { Semin Thromb Hemost 2012;38(1):31-37 }\end{array}$ \\
\hline $\begin{array}{l}\text { Giridhara Rao } \\
\text { Jayandharan }\end{array}$ & 2010 & $\begin{array}{l}\text { Jayandharan GR, Srivastava A, Srivastava A. Role of molecular genetics in hemophilia: } \\
\text { from diagnosis to therapy. Semin Thromb Hemost 2012;38(1):64-78 }\end{array}$ \\
\hline Timea Szanto & 2010 & $\begin{array}{l}\text { Szántó T, Joutsi-Korhonen L, Deckmyn H, Lassila R. New insights into von Willebrand } \\
\text { disease and platelet function. Semin Thromb Hemost 2012;38(1):55-63 }\end{array}$ \\
\hline Birgitta Salmela & 2010 & $\begin{array}{l}\text { Salmela B, Joutsi-Korhonen L, Armstrong E, Lassila R. Active online assessment of patients } \\
\text { using new oral anticoagulants: bleeding risk, compliance, and coagulation analysis. } \\
\text { Semin Thromb Hemost 2012;38(1):23-30 }\end{array}$ \\
\hline $\begin{array}{l}\text { Pia Riittaa-Maria } \\
\text { Siljander }\end{array}$ & 2010 & $\begin{array}{l}\text { Aatonen M, Grönholm M, Siljander PR. Platelet-derived microvesicles: multitalented parti- } \\
\text { cipants in intercellular communication. Semin Thromb Hemost 2012;38(1):102-113. }\end{array}$ \\
\hline
\end{tabular}


Table 2 (Continued)

\begin{tabular}{|c|c|c|}
\hline Awardee & $\begin{array}{l}\text { Year } \\
\text { awarded }\end{array}$ & Publication arising \\
\hline Romaric Lacroix & 2011 & $\begin{array}{l}\text { Lacroix R, Dignat-George F. Microparticles: new protagonists in pericellular and } \\
\text { intravascular proteolysis. Semin Thromb Hemost 2013;39(1):33-39 }\end{array}$ \\
\hline Brad McEwen & 2011 & $\begin{array}{l}\text { McEwen BJ, Morel-Kopp MC, Chen W, Tofler GH, Ward CM. Effects of omega-3 } \\
\text { polyunsaturated fatty acids on platelet function in healthy subjects and subjects with } \\
\text { cardiovascular disease. Semin Thromb Hemost } 2013 ; 39(1): 25-32\end{array}$ \\
\hline Neil A. Goldenberg & 2011 & $\begin{array}{l}\text { Bernard TJ, Armstrong-Wells J, Goldenberg NA. The institution-based prospective } \\
\text { inception cohort study: design, implementation, and quality assurance in pediatric } \\
\text { thrombosis and stroke research. Semin Thromb Hemost } 2013 ; 39(1): 10-14\end{array}$ \\
\hline Vivien Chen & 2011 & $\begin{array}{l}\text { Chen VM. Tissue factor de-encryption, thrombus formation, and thiol-disulfide } \\
\text { exchange. Semin Thromb Hemost 2013;39(1):40-47 }\end{array}$ \\
\hline Joseph E. Italiano, Jr. & 2011 & $\begin{array}{l}\text { Italiano JE Jr. Unraveling mechanisms that control platelet production. Semin Thromb } \\
\text { Hemost 2013;39(1):15-24 }\end{array}$ \\
\hline Vivian Xiaoyan Du & $2012 / 2013$ & $\begin{array}{l}\text { Du VX, Huskens D, Maas C, Al Dieri R, de Groot PG, de Laat B. New insights into the role of } \\
\text { erythrocytes in thrombus formation. Semin Thromb Hemost } 2014 ; 40(1): 72-80\end{array}$ \\
\hline Andrew Yee & $2012 / 2013$ & $\begin{array}{l}\text { Yee A, Kretz CA. Von Willebrand factor: form for function. Semin Thromb Hemost } \\
\text { 2014;40(1):17-27 }\end{array}$ \\
\hline Sarah O’Brien & $2012 / 2013$ & $\begin{array}{l}\text { O'Brien SH. Contraception-related venous thromboembolism in adolescents. Semin } \\
\text { Thromb Hemost 2014;40(1):66-71 }\end{array}$ \\
\hline Veronica Flood & $2012 / 2013$ & $\begin{array}{l}\text { Flood VH. Perils, problems, and progress in laboratory diagnosis of von Willebrand } \\
\text { disease. Semin Thromb Hemost 2014;40(1):41-48 }\end{array}$ \\
\hline Julie Tange & $2012 / 2013$ & $\begin{array}{l}\text { Tange JI, Grill D, Koch CD, et al. Local verification and assignment of mean normal } \\
\text { prothrombin time and International Sensitivity Index values across various instruments: } \\
\text { recent experience and outcome from North America. Semin Thromb Hemost 2014;40 } \\
(1): 115-120\end{array}$ \\
\hline Kent Chapman & $2012 / 2013$ & $\begin{array}{l}\text { Chapman K, Yuen S. Therapy for thrombotic thrombocytopenia purpura: past, present, } \\
\text { and future. Semin Thromb Hemost 2014;40(1):34-40 }\end{array}$ \\
\hline Andreas Tiede & 2014 & $\begin{array}{l}\text { Tiede A, Werwitzke S, Scharf RE. Laboratory diagnosis of acquired hemophilia a: } \\
\text { limitations, consequences, and challenges. Semin Thromb Hemost 2014;40(7):803-811 }\end{array}$ \\
\hline Wendy Lim & 2014 & $\begin{array}{l}\text { Lim W. Thrombotic risk in the antiphospholipid syndrome. Semin Thromb Hemost } \\
\text { 2014;40(7):741-746 }\end{array}$ \\
\hline $\begin{array}{l}\text { Susana Nobre } \\
\text { Fernandes }\end{array}$ & 2014 & $\begin{array}{l}\text { Fernandes S, Carvalho M, Lopes M, Araújo F. Impact of an individualized prophylaxis } \\
\text { approach on young adults with severe hemophilia. Semin Thromb Hemost 2014;40 } \\
\text { (7):785-789 }\end{array}$ \\
\hline $\begin{array}{l}\text { Maria Elisa } \\
\text { Mancuso }\end{array}$ & 2014 & $\begin{array}{l}\text { Mancuso ME, Fasulo MR. Thrombin generation assay as a laboratory monitoring tool } \\
\text { during by-passing therapy in patients with hemophilia and inhibitors. Semin Thromb } \\
\text { Hemost } 2016 ; 42(1): 30-35\end{array}$ \\
\hline Coen Maas & 2014 & $\begin{array}{l}\text { Tersteeg C, Fijnheer R, Deforche L, et al. Keeping von Willebrand factor under control: } \\
\text { alternatives for ADAMTS13. Semin Thromb Hemost 2016;42(1):9-17 }\end{array}$ \\
\hline Riten Kumar & 2014 & $\begin{array}{l}\text { Kumar R, Dunn A, Carcao M. Changing paradigm of hemophilia management: extended } \\
\text { half-life factor concentrates and gene therapy. Semin Thromb Hemost 2016;42(1):18-29 }\end{array}$ \\
\hline Juraj Sokol & 2015 & $\begin{array}{l}\text { Sokol J, Skerenova M, Jedinakova Z, et al. Progress in the understanding of sticky platelet } \\
\text { syndrome. Semin Thromb Hemost } 2017 ; 43(1): 8-13\end{array}$ \\
\hline Ljubica Jovanović & 2015 & $\begin{array}{l}\text { Jovanovic L, Antonijevic N, Novakovic T, et al. Practical aspects of monitoring of } \\
\text { antiplatelet therapy. Semin Thromb Hemost } 2017 ; 43(1): 14-23\end{array}$ \\
\hline Lucia Stanciakova & 2015 & $\begin{array}{l}\text { Stanciakova L, Dobrotova M, Jedinakova Z, et al. Monitoring of hemostasis and } \\
\text { management of anticoagulant thromboprophylaxis in pregnant women with increased } \\
\text { risk of fetal loss. Semin Thromb Hemost 2016;42(6):612-621 }\end{array}$ \\
\hline Tina Biss & 2015 & $\begin{array}{l}\text { Biss TT. Venous thromboembolism in children: is it preventable? Semin Thromb Hemost } \\
\text { 2016;42(6):603-611 }\end{array}$ \\
\hline Tobias Fuchs & 2015 & $\begin{array}{l}\text { Jiménez-Alcázar M, Kim N, Fuchs TA. Circulating extracellular DNA: cause or consequence } \\
\text { of thrombosis? Semin Thromb Hemost 2017;43(6):553-561 }\end{array}$ \\
\hline
\end{tabular}


Table 2 (Continued)

\begin{tabular}{|l|l|l|}
\hline Awardee & $\begin{array}{l}\text { Year } \\
\text { awarded }\end{array}$ & Publication arising \\
\hline Jonathan M. Coutinho & 2015 & $\begin{array}{l}\text { Silvis SM, Middeldorp S, Zuurbier SM, Cannegieter SC, Coutinho JM. Risk factors for } \\
\text { cerebral venous thrombosis. Semin Thromb Hemost 2016;42(6):622-631 }\end{array}$ \\
\hline Soundarya Selvam & 2016 & $\begin{array}{l}\text { Selvam S, James P. Angiodysplasia in von Willebrand disease: understanding the clinical } \\
\text { and basic science. Semin Thromb Hemost 2017;43(6):572-580 }\end{array}$ \\
\hline Vincent Muczynski & 2016 & $\begin{array}{l}\text { Muczynski V, Christophe OD, Denis CV, Lenting PJ. Emerging therapeutic strategies in } \\
\text { the treatment of hemophilia A. Semin Thromb Hemost 2017;43(6):581-590 }\end{array}$ \\
\hline Karen Schreiber & 2016 & $\begin{array}{l}\text { Schreiber K, Breen K, Cohen H, et al. HYdroxychloroquine to improve pregnancy } \\
\text { outcome in women with AnTlphospholipid Antibodies (HYPATIA) Protocol: a multi- } \\
\text { national randomized controlled trial of hydroxychloroquine versus placebo in addition to } \\
\text { standard treatment in pregnant women with antiphospholipid syndrome or antibodies. } \\
\text { Semin Thromb Hemost 2017;43(6):562-571 }\end{array}$ \\
\hline Jasmine Wee & 2016 & $\begin{array}{l}\text { Tay J, Tiao J, Hughes Q, Jorritsma J, Gilmore G, Baker R. Circulating microRNA as } \\
\text { thrombosis sentinels: caveats and considerations. Semin Thromb Hemost 2018. } \\
\text { doi: 10.1055/s-0037-1606568 }\end{array}$ \\
\hline Adi J. Klil-Drori & 2016 & $\begin{array}{l}\text { Klil-Drori AJ, Tagalakis V. Direct oral anticoagulants in end-stage renal disease. Semin } \\
\text { Thromb Hemost 2018. DOI: https://doi.org/10.1055/s-0037-1621715. }\end{array}$ \\
\hline Lindsey A. George & 2016 & \begin{tabular}{l} 
Submission still pending \\
\hline Ivar van Asten
\end{tabular} \\
\hline
\end{tabular}

the "most popular" 2012-2013 list. $^{22}$ Also motivating is that a few of the Young Investigator awardees were also included as authors on other contributions to Seminars in Thrombosis $\mathcal{E}$ Hemostasis that were also listed in these most popular listings, including another 2014 Most Popular award winner. ${ }^{51}$

These findings act to validate the Young Investigator award process, and I look forward to seeing their careers continue to develop. These findings also suggest that future Young Investigator awardees have very high bars established, and I wish them the best of luck to exceed the precedence set by earlier awardees.

I would like as always to congratulate the current Young Investigator awardees for their awards, and will also take the opportunity to thank previous Young Investigator awardees for their contributions; these have obviously been well received by readers of this journal. I look forward to reading, and monitoring the future popularity, of the contributions from the latest group of Young Investigators!

\section{References}

1 Favaloro EJ. Editorial. Welcome to a special issue of Seminars in Thrombosis and Hemostasis-The Closing Issue for 2008. Semin Thromb Hemost 2008;34:693-696

2 Favaloro EJ. A tribute to Eberhard F. Mammen, M.D. (1930-2008). Semin Thromb Hemost 2008;34(08):703-707

3 Favaloro EJ. Editorial. Welcome to the first issue of Seminars in Thrombosis and Hemostasis for 2009. Semin Thromb Hemost 2009;35:1-2

4 Favaloro EJ. Editorial. Winners of the inaugural Eberhard F. Mammen award for most popular article. Semin Thromb Hemost 2009; 35:587-590

5 Favaloro EJ. Editorial. 2009 Eberhard F. Mammen Young Investigator Award Winners. Semin Thromb Hemost 2010;36:469-470
6 Favaloro EJ. Winners of the 2010 Eberhard F. Mammen award for most popular article during 2008-2009. Semin Thromb Hemost 2010;36(07):685-692

7 Favaloro EJ. 2011 Eberhard F. Mammen award announcements. Semin Thromb Hemost 2011;37(05):431-439

8 Favaloro EJ. 2012 Eberhard F. Mammen award announcements. Semin Thromb Hemost 2012;38:425-432

9 Favaloro EJ. Eberhard F. Mammen award announcements. Semin Thromb Hemost 2013;39:567-574

10 Favaloro EJ. 2014 Eberhard F. Mammen award announcements: part I-most popular articles. Semin Thromb Hemost 2014;40(04): 407-412

11 Favaloro EJ. 2014 Eberhard F. Mammen award announcements: part II-Young Investigator Awards. Semin Thromb Hemost 2014; 40(07):718-723

12 Favaloro EJ. 2015 Eberhard F. Mammen award announcements: part I-most popular articles. Semin Thromb Hemost 2015;41 (07):673-679

13 Favaloro EJ. 2015 Eberhard F. Mammen award announcements: part II-Young Investigator Awards. Semin Thromb Hemost 2015; 41(08):809-815

14 Favaloro EJ. 2016 Eberhard F. Mammen award announcements: part I-most popular articles. Semin Thromb Hemost 2016;42 (04):325-330

15 Favaloro EJ. 2016 Eberhard F. Mammen award announcements: part II-Young Investigator Awards. Semin Thromb Hemost 2017; 43(03):235-241

16 Favaloro EJ. 2017 Eberhard F. Mammen award announcements: part I-most popular articles. Semin Thromb Hemost 2017;43 (04):357-363

17 Lijfering WM, Flinterman LE, Vandenbroucke JP, Rosendaal FR, Cannegieter SC. Relationship between venous and arterial thrombosis: a review of the literature from a causal perspective. Semin Thromb Hemost 2011;37(08):885-896

18 Pels SG. Current therapies in primary immune thrombocytopenia. Semin Thromb Hemost 2011;37(06):621-630 
19 Cuker A. Current and emerging therapeutics for heparin-induced thrombocytopenia. Semin Thromb Hemost 2012;38(01):31-37

20 Jayandharan GR, Srivastava A, Srivastava A. Role of molecular genetics in hemophilia: from diagnosis to therapy. Semin Thromb Hemost 2012;38(01):64-78

21 Szántó T, Joutsi-Korhonen L, Deckmyn H, Lassila R. New insights into von Willebrand disease and platelet function. Semin Thromb Hemost 2012;38(01):55-63

22 Salmela B, Joutsi-Korhonen L, Armstrong E, Lassila R. Active online assessment of patients using new oral anticoagulants: bleeding risk, compliance, and coagulation analysis. Semin Thromb Hemost 2012;38(01):23-30

23 Aatonen M, Grönholm M, Siljander PR. Platelet-derived microvesicles: multitalented participants in intercellular communication. Semin Thromb Hemost 2012;38(01):102-113

24 Lacroix R, Dignat-George F. Microparticles: new protagonists in pericellular and intravascular proteolysis. Semin Thromb Hemost 2013;39(01):33-39

25 McEwen BJ, Morel-Kopp MC, Chen W, Tofler GH, Ward CM. Effects of omega-3 polyunsaturated fatty acids on platelet function in healthy subjects and subjects with cardiovascular disease. Semin Thromb Hemost 2013;39(01):25-32

26 Bernard TJ, Armstrong-Wells J, Goldenberg NA. The institutionbased prospective inception cohort study: design, implementation, and quality assurance in pediatric thrombosis and stroke research. Semin Thromb Hemost 2013;39(01):10-14

27 Italiano JE Jr. Unraveling mechanisms that control platelet production. Semin Thromb Hemost 2013;39(01):15-24

28 Du VX, Huskens D, Maas C, Al Dieri R, de Groot PG, de Laat B. New insights into the role of erythrocytes in thrombus formation. Semin Thromb Hemost 2014;40(01):72-80

29 Yee A, Kretz CA. Von Willebrand factor: form for function. Semin Thromb Hemost 2014;40(01):17-27

30 O'Brien SH. Contraception-related venous thromboembolism in adolescents. Semin Thromb Hemost 2014;40(01):66-71

31 Flood VH. Perils, problems, and progress in laboratory diagnosis of von Willebrand disease. Semin Thromb Hemost 2014;40(01): 41-48

32 Tange JI, Grill D, Koch CD, et al. Local verification and assignment of mean normal prothrombin time and International Sensitivity Index values across various instruments: recent experience and outcome from North America. Semin Thromb Hemost 2014;40 (01):115-120

33 Chapman K, Yuen S. Therapy for thrombotic thrombocytopenia purpura: past, present, and future. Semin Thromb Hemost 2014; 40(01):34-40

34 Tiede A, Werwitzke S, Scharf RE. Laboratory diagnosis of acquired hemophilia A: limitations, consequences, and challenges. Semin Thromb Hemost 2014;40(07):803-811

35 Lim W. Thrombotic risk in the antiphospholipid syndrome. Semin Thromb Hemost 2014;40(07):741-746
36 Fernandes S, Carvalho M, Lopes M, Araújo F. Impact of an individualized prophylaxis approach on young adults with severe hemophilia. Semin Thromb Hemost 2014;40(07):785-789

37 Mancuso ME, Fasulo MR. Thrombin generation assay as a laboratory monitoring tool during by-passing therapy in patients with hemophilia and inhibitors. Semin Thromb Hemost 2016;42(01):30-35

38 Tersteeg C, Fijnheer R, Pasterkamp G, et al. Keeping von Willebrand factor under control: alternatives for ADAMTS13. Semin Thromb Hemost 2016;42(01):9-17

39 Kumar R, Dunn A, Carcao M. Changing paradigm of hemophilia management: extended half-life factor concentrates and gene therapy. Semin Thromb Hemost 2016;42(01):18-29

40 Sokol J, Skerenova M, Jedinakova Z, et al. Progress in the understanding of sticky platelet syndrome. Semin Thromb Hemost 2017;43(01):8-13

41 Jovanovic L, Antonijevic N, Novakovic T, et al. Practical aspects of monitoring of antiplatelet therapy. Semin Thromb Hemost 2017; 43(01):14-23

42 Stanciakova L, Dobrotova M, Jedinakova Z, et al. Monitoring of hemostasis and management of anticoagulant thromboprophylaxis in pregnant women with increased risk of fetal loss. Semin Thromb Hemost 2016;42(06):612-621

43 Biss TT. Venous thromboembolism in children: is it preventable? Semin Thromb Hemost 2016;42(06):603-611

44 Jiménez-Alcázar M, Kim N, Fuchs TA. Circulating extracellular DNA - cause or consequence of thrombosis? Semin Thromb Hemost 2017;43(06):553-561

45 Silvis SM, Middeldorp S, Zuurbier SM, Cannegieter SC, Coutinho JM. Risk factors for cerebral venous thrombosis. Semin Thromb Hemost 2016;42(06):622-631

46 Selvam S, James P. Angiodysplasia in von Willebrand disease: understanding the clinical and basic science. Semin Thromb Hemost 2017;43(06):572-580

47 Muczynski V, Christophe OD, Denis CV, Lenting PJ. Emerging therapeutic strategies in the treatment of hemophilia A. Semin Thromb Hemost 2017;43(06):581-590

48 Schreiber K, Breen K, Cohen H, et al. HYdroxychloroquine to Improve Pregnancy Outcome in Women with AnTIphospholipid Antibodies (HYPATIA) Protocol: a multinational randomized controlled trial of hydroxychloroquine versus placebo in addition to standard treatment in pregnant women with antiphospholipid syndrome or antibodies. Semin Thromb Hemost 2017;43(06):562-571

49 Tay J, Tiao J, Hughes Q Jorritsma J, Gilmore G, Baker R. Circulating microRNA as thrombosis sentinels: caveats and considerations. Semin Thromb Hemost 2018. Doi: 10.1055/s-0037-1606568

50 Klil-Drori AJ, Tagalakis V. Direct oral anticoagulants in end-stage renal disease. Semin Thromb Hemost 2018. Doi: https://doi.org/ $10.1055 / \mathrm{s}-0037-1621715$

51 Chapman K, Seldon M, Richards R. Thrombotic microangiopathies, thrombotic thrombocytopenic purpura, and ADAMTS-13. Semin Thromb Hemost 2012;38(01):47-54 